\title{
The Serology and Pathogenicity of the Genus Chromobacterium
}

\author{
By P. H. A. SNEATH \\ National Institute for Medical Research, Mill Hill, London, N.W.7 \\ AND F. E. BUCKLAND \\ Microbiological Research Department, Ministry of Supply, Porton, Wiltshire
}

SUMMARY: Mesophilic strains of the genus Chromobacterium were found to crossagglutinate extensively, and much of this appears to be due to common rough somatic antigens. The psychrophilic strains also cross-agglutinated to some extent. There was little cross-agglutination between mesophils and psychrophils. Neither mesophils nor psychrophils showed clear-cut antigenic subgroups. Many mesophilic strains, whether isolated from naturally-occurring cases of infection or from water, were found to be virulent for experimental animals. The most virulent were strains from two cases of human infection, which had an LD50 dose for guinea-pigs of c. $5 \times 10^{6}$ viable organisms. The virulent strains did not form a homogeneous antigenic group. Cultures of mesophils contained an endotoxin, but no exotoxin was found. The experimental disease may be an acute, rapidly fatal septicaemia, or a more chronic disease with multiple abscess formation like that found in natural infections; occasionally a local abscess with subsequent recovery was the only result of the injection of cultures.

The generic name Chromobacterium is used here in the restricted sense of the 'Bacterium violaceum group', excluding red and yellow chromogens such as 'Bacillus prodigiosus' (Serratia marcescens). There are two main types of Chromobacterium, both of which in the past have usually been called Chromobacterium violaceum, and which may conveniently be regarded as two species; but since the correct names for these two species are uncertain (Sneath, 1956a), they are referred to here as the 'mesophils' and the 'psychrophils'. The former usually ferment glucose anaerobically, are markedly proteolytic, facultatively anaerobic, and give a positive egg-yolk reaction, but do not hydrolyse aesculin. The psychrophilic organisms produce acid from glucose but only aerobically, are poorly proteolytic, strictly aerobic and hydrolyse aesculin but do not produce an egg-yolk reaction. Infections by Chromobacterium strains are rare, and are produced only by mesophilic strains. Most of the recorded cases to date were listed by Sneath, Whelan, Singh \& Edwards (1953). Other instances are those described by Floch \& de Lajudie (1943) in cattle, and by Audebaud, Gazin, Ceccaldi \& Merveille (1954) in a monkey; the strains examined by these authors have unfortunately been lost (Floch, personal communication; Audebaud, personal communication). In addition, some strains were kindly sent to us which had been isolated from cases of disease in cattle and pigs by Sippel, Medina \& Atwood (1954), in a pig by Sippel (1955) and in man by Darrasse, Mazaud, Giudicelli \& Camain (1955). Further records of 
infection were briefly reported by Broudin (1922) in a wild boar, by Joubert \& Nguyen-van-Liem (1957) in buffaloes: Dr J. P. F. Whelan (personal communication) recently isolated a strain in pure culture from the brain of a pet monkey which was thought to have died of rabies in Singapore but from which no rabies virus was recovered, and which was presumably a case of chromobacterial septicaemia.

Most authors who have described relevant infections have made some study of the pathogenicity of their strains and have examined their virulence for laboratory animals by the injection of relatively large inocula (e.g. Woolley, 1904, 1905; Schattenberg \& Harris, 1942), but no estimates of virulence based on viable counts have, as far as we can ascertain, been published. There is little work on the serology of the group other than that of Bampton (1913).

\section{METHODS}

Strains and media. The strains used were those described by Sneath $(1956 a)$ and the media were prepared as described in that paper. The nutrient broth used was that of Hartley (1922) and nutrient agar was made by adding to this $1.5 \%(w / v)$ of Japanese agar. The strains BHR/1 and BNR/1 were rough variants of the strains $\mathbf{B H}$ and $\mathbf{B N}$ respectively. The rough variants were obtained by growth of the latter strains in nutrient broth containing, respectively, sterile anti-BH or anti-BN ' $O$ ' sera. They were only slightly rough (both colonially and antigenically) as compared with very rough strains such as SH or AM.

Serological methods. For the preparation of suspensions for immunization and agglutination, mesophilic strains were grown routinely for $24 \mathrm{hr}$. at $30^{\circ}$ and psychrophilic strains for $48 \mathrm{hr}$. at $25^{\circ}$. Antisera were prepared by injecting killed organisms intravenously into rabbits three times a week until the animals had received six injections, in doses increasing from $c .10^{7}$ to $c .5 \times 10^{8}$ organisms; the animals were bled 10 days after the last injection. The sera were either stored at $-20^{\circ}$, or, after mixing with an equal volume of glycerol, at $4^{\circ}$. No decrease in titre has been noticed after five years of storage by either method.

' $O$ ' antisera were prepared by injecting suspensions washed from $24 \mathrm{hr}$. nutrient agar slope cultures and heated at $100^{\circ}$ for $2 \mathrm{hr}$. ' $\mathrm{OH}$ ' antisera were prepared by injecting nutrient broth cultures killed by the addition of sufficient formalin to give a final concentration of $0.04 \%(\mathrm{w} / \mathrm{v})$ of formaldehyde.

Agglutinable suspensions were diluted with $0 \cdot 17(\mathrm{w} / \mathrm{v})$ sodium chloride solution (this was used to decrease the autoagglutination of rough strains) until they had an opacity 0.55 times that of the International Opacity Standard (World Health Organization, 1954), i.e. 5.5 Opacity Units, which is about equivalent to an optical density of 0.33 in a $1 \mathrm{~cm}$. cell with an Ilford $\mathbf{H 5 0 8}$ neutral grey filter. Titrations were performed by diluting antisera in twofold steps in $0.17 \%(\mathrm{w} / \mathrm{v}) \mathrm{NaCl}$, and mixing $0.25 \mathrm{ml}$. volumes of the dilutions with $\mathbf{0 . 2 5} \mathrm{ml}$. volumes of bacterial suspension in Dreyer's tubes, and then incubating them. The titre recorded is the reciprocal of the final dilution of antiserum in the last tube which showed agglutination visible to the naked eye. 
To demonstrate $\mathrm{O}$ agglutination anti-O serum was mixed with living suspensions of organisms grown in nutrient broth, and incubated for $4 \mathrm{hr}$. at $56^{\circ}$ followed by $18 \mathrm{hr}$. at room temperature. To demonstrate $\mathrm{H}$ agglutination due to polar flagella, ' $\mathrm{OH}$ ' antiserum was incubated at $56^{\circ}$ for $18 \mathrm{hr}$. with suspensions of organisms grown in nutrient broth and formolized as described above. To demonstrate $\mathbf{H}$ agglutination due to lateral flagella, the ' $H$ ' or ' $\mathrm{OH}$ ' sera were incubated for $2 \mathrm{hr}$. at $56^{\circ}$ with formolized suspensions of bacteria grown on nutrient agar plates for $18 \mathrm{hr}$. The suspensions for $\mathrm{H}$ agglutination were examined by flagella staining to confirm the flagellation.

During the latter part of this work a large number of psychrophilic strains were received and it was not practicable to make antisera to them all. Antisera were made only to a few strains and the numerous combinations of antiserum and strain were first tested by slide agglutination with concentrated serum and living suspensions from nutrient agar plates. Only those mixtures which showed agglutination on the slides were then titrated in tubes. Such slide tests revealed agglutination due to polar $\mathbf{H}$ antigens as well as the other antigens; it is unlikely that any significant cross-reactions were missed by this screening procedure.

Pathogenicity. Rabbits (2 kg.), guinea-pigs (250 g.) and white mice (20 g.; Porton strain) were used. The inocula were aerobic nutrient broth cultures grown for $24 \mathrm{hr}$. at $37^{\circ}$ (for the psychrophilic strain NT at $25^{\circ}$ for $48 \mathrm{hr}$.). Tenfold dilutions were made in 0.03 M-potassium phosphate buffer ( $\mathrm{pH} \mathrm{7 \cdot 6)}$ and $0.1 \mathrm{ml}$. volumes of suitable dilutions were inoculated into animals within $30 \mathrm{~min}$. of making the dilutions. The animals were observed for 1 week, when the death-rate was scored. Viable counts of the inocula were made by the drop method (Miles \& Misra, 1938) on nutrient agar plates containing $5 \%$ $(\mathrm{v} / \mathrm{v})$ peptic digest of sheep's blood (Fildes, 1920). The diluent was 0.03 Mpotassium phosphate buffer ( $\mathrm{pH} 7 \cdot 6)$. Colonies were counted after incubation for $24 \mathrm{hr}$. at $30^{\circ}\left(48 \mathrm{hr}\right.$. at $20^{\circ}$ for psychrophilic strains).

Autopsy and histology. Animals which died from infection or toxic effects were autopsied. Samples of blood from the heart and tissue samples from any visible lesions in the liver and spleen were inoculated into nutrient broth. After incubation at $30^{\circ}$ for $48 \mathrm{hr}$. $\left(20^{\circ}\right.$ for $48 \mathrm{hr}$. for psychrophilic strains) the broth cultures were plated out on blood agar plates to confirm the presence of the organism. Material for histology was fixed in $10 \%(v / v)$ formol saline; paraffin sections were stained by routine methods.

\section{RESULTS}

\section{Antigenic structure}

$O$ antigens. The treatment of the suspensions used for agglutination had a considerable effect on the pattern of agglutination with different sera. Both ethanol treatment and heating of organisms at $100^{\circ}$ usually caused a decrease in titre of $\mathbf{O}$ antiserum against the homologous strain, while cross-reactions with sera against other strains became more marked. Some of the 'rough' strains became more strongly autoagglutinable after heating to $100^{\circ}$. For- 


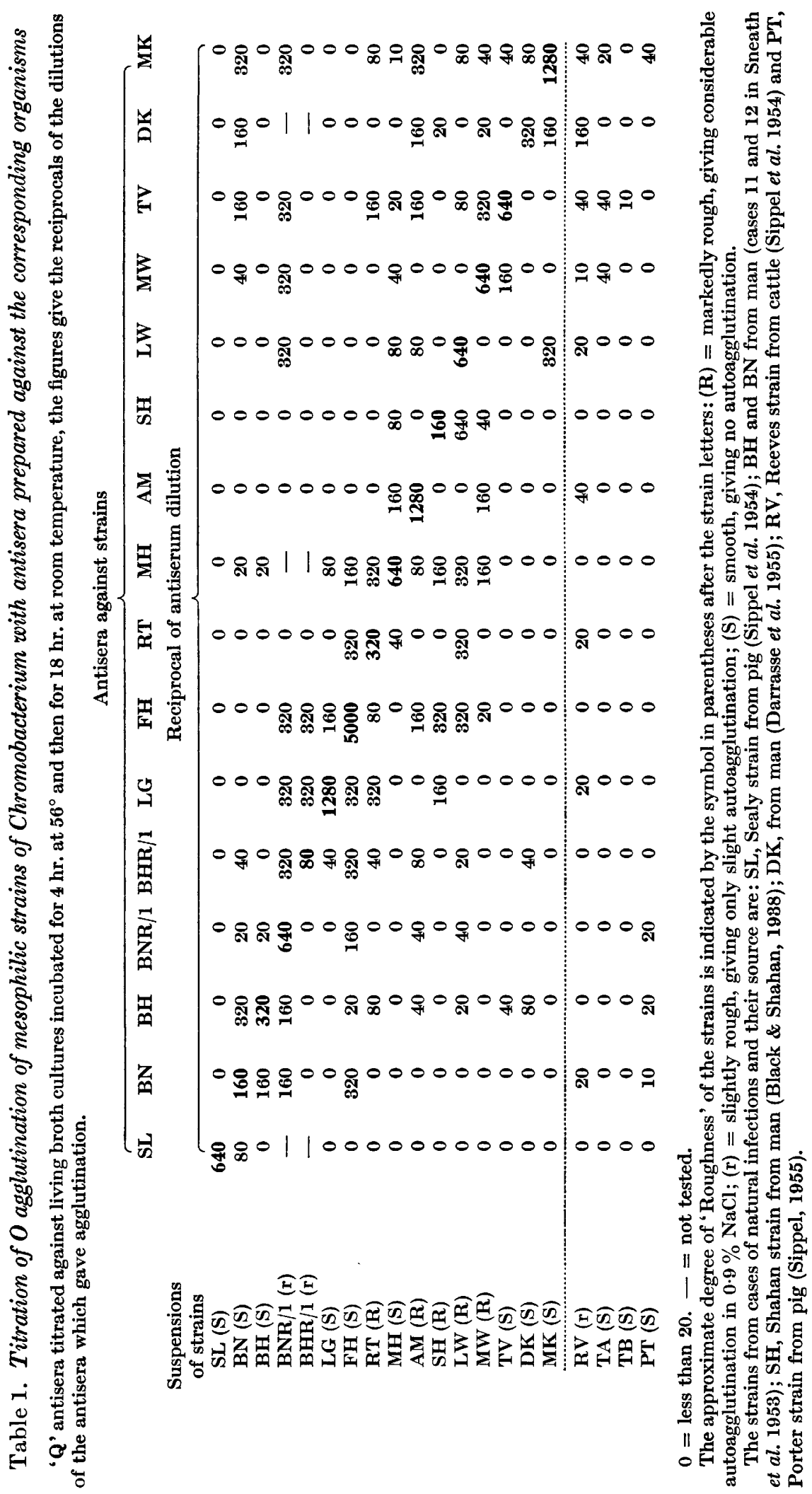


molized polar flagellated suspensions gave titres similar to those obtained with living suspensions, but partial inhibition of $\mathbf{O}$ agglutination was found when formolized peritrichous suspensions were used. The results reported here were obtained with living suspensions; they are recorded in Tables 1 and 2 which show, respectively, the agglutination titres of antisera against mesophilic strains with suspensions of mesophilic strains, and the titres of antisera against psychrophilic strains with suspensions of psychrophilic strains.

Table 2. The titration of $O$ antisera prepared against psychrophils with psychrophilic strains of Chromobacterium

The ' $O$ ' antisera were titrated against living broth cultures incubated for $4 \mathrm{hr}$. at $56^{\circ}$ and then for $18 \mathrm{hr}$. at room temperature.

All these psychrophilic strains were culturally 'smooth'.

\begin{tabular}{|c|c|c|c|c|c|c|c|}
\hline \multirow{3}{*}{$\begin{array}{l}\text { Suspensions } \\
\text { of strains }\end{array}$} & \multicolumn{7}{|c|}{ Antisera against strains } \\
\hline & NT & EC & $\mathrm{NC}$ & $\mathbf{P B}$ & HB & HE & MB \\
\hline & \multicolumn{7}{|c|}{ Reciprocal of dilution of antisera } \\
\hline $\mathbf{N} \mathbf{T}$ & 160 & $\mathbf{0}$ & $\mathbf{0}$ & 0 & $\mathbf{0}$ & $\mathbf{0}$ & $\mathbf{0}$ \\
\hline EC & $\mathbf{0}$ & 160 & 40 & 0 & $\mathbf{0}$ & $\mathbf{0}$ & $\mathbf{0}$ \\
\hline NC & $\mathbf{0}$ & $\mathbf{0}$ & 320 & 160 & $\mathbf{0}$ & $\mathbf{0}$ & 0 \\
\hline PB & $\mathbf{0}$ & $\mathbf{0}$ & 10 & 160 & 0 & $\mathbf{0}$ & $\mathbf{0}$ \\
\hline HB & $\mathbf{0}$ & $\mathbf{0}$ & 0 & 0 & 2560 & $\mathbf{0}$ & $\mathbf{0}$ \\
\hline HE & $\mathbf{0}$ & $\mathbf{0}$ & 0 & $\mathbf{0}$ & 40 & 80 & 0 \\
\hline MB & 0 & 0 & o & 0 & $\mathbf{0}$ & 0 & 160 \\
\hline $\mathbf{E A}$ & 0 & 80 & $\mathbf{0}$ & 0 & 0 & 0 & 0 \\
\hline $\mathbf{H W}$ & o & 0 & 160 & 80 & o & 0 & 0 \\
\hline$\overline{\mathbf{G A}}$ & 0 & 0 & 80 & 0 & o & 0 & 0 \\
\hline MA & 0 & 0 & 160 & 0 & o & 0 & 0 \\
\hline DA & o & 0 & 0 & 40 & 0 & 0 & 0 \\
\hline IN & 0 & 0 & 0 & 20 & 10 & 0 & 0 \\
\hline HA & 0 & 0 & 0 & 0 & 40 & 10 & 0 \\
\hline EB & 0 & 0 & 0 & 0 & 0 & 0 & 0 \\
\hline MC & 0 & 0 & 0 & 0 & 0 & 0 & 0 \\
\hline HC & 0 & 0 & 0 & 0 & 0 & 0 & $\mathbf{0}$ \\
\hline $\mathbf{H F}$ & 0 & 0 & 0 & 0 & 0 & 0 & 0 \\
\hline CA & 0 & 0 & 0 & 0 & 0 & 0 & 0 \\
\hline RU & 0 & 0 & 0 & 0 & 0 & o & 0 \\
\hline
\end{tabular}

There were a few instances of definite cross-agglutination between mesophilic and psychrophilic strains, and the tests are therefore not given in table form; these instances of cross-agglutination are listed below. Probably most of the weak cross-reactions were not due to common antigens, since normal rabbit sera often agglutinated some strains of Chromobacterium to a titre of 20 or $\mathbf{4 0 ,}$ but not higher.

(1) Agglutination of mesophilic strains by antisera against psychrophils: anti-NT had a titre of 160 with strain AM and of 40 with strain $\mathrm{LW}$; anti-HE had a titre of 40 with strain $A M$ and of 80 with strain $\mathrm{MH}$; anti-EC had a titre of 20 with strains $\mathrm{MH}$ and $\mathrm{DK}$; anti-MB had a titre of 80 with strain $\mathrm{MH}$; anti-HB had a titre of 160 with strain MH. 
(2) Agglutination of psychrophilic strains by antisera against mesophils: anti-LG had a titre of 320 with strain NT; anti-MK had a titre of 20 with strain NT.

It will be seen from Table 1 that the mesophilic strains did not fall into clearly marked groups, although there were several which were closely related, such as strains $\mathrm{BH}$ and $\mathrm{BN}, \mathbf{F H}$ and LG, MW and TV. It is also seen that rough strains cross-agglutinated more often than did smooth strains. It seems probable that this was due to the uncovering of deep somatic antigens possessed in common, since the rough variants of strains $\mathrm{BH}$ and $\mathrm{BN}$ (BHR/1 and $\mathrm{BNR} / 1$ respectively) agglutinated with sera which did not agglutinate their parent strains. Leifson (1956) separated the mesophilic strains which do not produce acid from carbohydrates under anaerobic conditions as a distinct species. Strains of this biochemical pattern are RT, MH, SH and LW; serologically they do not seem to form a distinct group. It will be seen from Table 2 that many of the antisera to psychrophils were almost strain specific, but that there were sufficient cross-reactions to confirm that the psychrophilic strains formed an antigenically related group. Bearing in mind the limited number of antisera and the absence of rough strains, the general behaviour of the psychrophils appears to be much the same as was found with the mesophils.

$H$ antigens. The results of agglutination of broth cultures by ' $\mathrm{OH}$ ' antisera (at $56^{\circ}$ for $4 \mathrm{hr}$.) were usually very similar to those obtained with ' $\mathrm{O}$ ' antisera. This observation was explained when it was found that the broth cultures usually possessed only polar flagella, which do not give good agglutination unless the tests are incubated at $56^{\circ}$ overnight. The agglutination observed after $4 \mathrm{hr}$. was therefore mainly $\mathrm{O}$ agglutination. The preparation of pure polar ' $H$ ' antisera has not been possible, but it was shown by Sneath (1956 $b$ ) that the antigens of the lateral flagella ('peritrichate' flagella) are different from the polar flagellar antigens. The typical $H$ agglutination found with peritrichate organisms can be obtained using ' $\mathrm{OH}$ ' antisera and peritrichate suspensions (consisting of organisms which possess both a polar flagellum and also lateral flagella) of young cultures on agar. The only detailed work with $\mathbf{H}$ antigens was with five of the strains from natural infections (sources noted in Table 1). It was of interest to see whether these strains possessed common $\mathrm{H}$ antigens. The ' $\mathrm{OH}$ ' antisera, although prepared by immunizing with polarly flagellate suspensions, contained enough lateral $H$ antibody to enable them to be used (after removing $\mathrm{O}$ and polar $\mathrm{H}$ antibodies by absorption with homologous polarly flagellate organisms, Sneath (1956b)). The existence of two forms of flagella also explains why some slide tests (with nutrient agar cultures, which would yield peritrichously flagellate organisms) were positive when tube tests (with polarly flagellate organisms from broth cultures) were negative.

A point of interest is whether there is any antigen common to the more virulent strains or to those which caused natural infections. The strains isolated from natural infections are strains $\mathrm{BH}, \mathrm{BN}, \mathrm{SH}, \mathrm{SL}, \mathrm{DK}, \mathrm{RV}$ and PT (see Table 1), while the most virulent of those isolated from other sources are strains LG and MK (see Table 4). There was no evidence of an $\mathbf{O}$ antigen (see 
Table 1) common to these strains. Some of these strains were also examined for polar and lateral flagellar agglutination. The results are given in Table 3, in which it is seen that there appeared to be no $\mathrm{H}$ antigen common to all the strains examined although strains $\mathrm{BN}$ and SL had a lateral $\mathbf{H}$ antigen in common.

\section{Table 3. Agglutination of Chromobacterium strains due to flagellar antigens}

I. Agglutination due to $\mathbf{O}$ and polar $\mathbf{H}$ antigens. Agglutination titres of antisera containing $\mathbf{O}$ and $\mathrm{H}$ antibodies with living suspensions possessing polar flagella but no lateral (peritrichous) flagella, incubated at $56^{\circ}$ for $18 \mathrm{hr}$.

\begin{tabular}{|c|c|c|c|c|c|}
\hline \multirow{3}{*}{$\begin{array}{c}\text { Suspensions } \\
\text { of strains }\end{array}$} & \multicolumn{5}{|c|}{ Antisera against strains } \\
\hline & BH & BN & SL & SH & DK \\
\hline & \multicolumn{5}{|c|}{ Reciprocal of dilution of antisera } \\
\hline BH & 80 & 160 & 1.60 & 80 & 160 \\
\hline $\mathbf{B N}$ & 1280 & 320 & 640 & 160 & 40 \\
\hline SL & 10 & 80 & 640 & $\mathbf{0}$ & $\mathbf{0}$ \\
\hline SH & 80 & 40 & 20 & 640 & 10 \\
\hline DK & 40 & 160 & 80 & 40 & 640 \\
\hline
\end{tabular}

II. Agglutination due to lateral (peritrichous) $\mathbf{H}$ antigens. Agglutination titres of $\mathbf{H}$ antisera (absorbed with homologous boiled organisms to remove $\mathrm{O}$ antibodies) with suspensions possessing lateral (peritrichous) flagella, incubated at $56^{\circ}$ for only $2 \mathrm{hr}$. to avoid agglutination due to polar flagella.

\begin{tabular}{|c|c|c|c|c|c|}
\hline \multirow{3}{*}{$\begin{array}{l}\text { Suspensions } \\
\text { of strains }\end{array}$} & \multicolumn{5}{|c|}{ Antisera against strains } \\
\hline & $\mathbf{B H}$ & $\mathbf{B N}$ & SL & SH & DK \\
\hline & \multicolumn{5}{|c|}{ Reciprocal of dilution of antisera } \\
\hline BH & \multicolumn{5}{|c|}{ No peritrichous suspensions obtainable } \\
\hline $\mathrm{BN}$ & 1280 & 160 & 160 & 0 & 0 \\
\hline SL & 640 & 40 & 80 & 10 & $\mathbf{0}$ \\
\hline SH & $\mathbf{0}$ & 0 & 0 & 320 & 0 \\
\hline DK & $\mathbf{0}$ & 0 & $\mathbf{0}$ & $\mathbf{0}$ & 1280 \\
\hline
\end{tabular}

Antigenic relationship to other chromogenic bacteria. All the antisera against Chromobacterium strains were slide-tested against living suspensions of two strains of Whitmore's bacillus, Pseudomonas iodinum (strains TE and RE), Corynebacterium viscosum (strain GR) and six stock strains of 'Bacillus prodigiosus' (Serratia marcescens). No agglutination was found in any instance. Polyvalent ' $\mathrm{OH}$ ' antisera against six strains of 'Bacillus prodigiosus' and an antiserum to Whitmore's bacillus did not agglutinate any strain of Chromobacterium. Strain TI (Chromobacterium ianthinum of Gilman, 1953) was tested with all the Chromobacterium antisera, and an $\mathrm{OH}$ antiserum against TI was tested with all Chromobacterium strains: a few doubtful reactions were found which were negative when tested by tube agglutination. These negative results are in keeping with the opinion that none of these other chromogenic organisms belong to the genus Chromobacterium (Sneath, 1956a); nor does Whitmore's bacillus.

Phase variation. Strain DK was examined to discover whether it possessed 
alternative antigenic phases of the lateral flagella, analogous to the Salmonella flagellar antigen phases, but no evidence of this was found by using standard techniques.

\section{Pathogenicity}

The majority of the mesophils were tested for pathogenicity, and it may be seen from Table 4 that the virulence of different strains varied widely, from highly virulent strains such as $\mathbf{B N}$ and $\mathbf{B H}$, to strains like $\mathbf{A M}$ and the psychrophil NT, which were only lethal in huge doses and which probably caused death by intoxication. None of the rough strains was very virulent, and two rough variants of virulent strains, $\mathrm{BHR} / 1$ and $\mathrm{BNR} / 1, \mathrm{had}_{\mathrm{a}}^{\mathrm{x}} \mathrm{a}$ greatly decreased virulence as compared with the parental strains.

Post-mortem and histological appearances. With highly virulent strains the injection of a large dose of living organisms ( $c .5$ times the LD 50 dose) caused death by septicaemia, often in $18 \mathrm{hr}$. The only post-mortem appearances were congestion of the abdominal viscera, with a slightly'enlarged spleen, some general subcutaneous congestion and a little turbid or blood-stained fluid in the pleural and peritoneal cavities. After the subcutaneous injection of living organisms, there was oedema, often gelatinous, and congestion around the inoculation site with perhaps some haemorrhage. The less virulent strains gave smaller local lesions. The organism was readily recovered from the blood and all the organs. Histological changes were very slight.

The effect of doses of living organisms near the LD50 dose was variable. Some animals developed septicaemia, some showed only a necrotic local lesion (after subcutaneous injection) which might ulcerate, and then slowly heal. A few animals developed pyaemia as is seen in man and in swine, with fever, anorexia, dyspnoea and rapid wasting, usually causing death after some days. At autopsy, abscesses were found in the liver and commonly also in the lungs and spleen, from which the organism was readily cultivated. The abscesses were similar in histological appearance to those seen in natural infections. The predominant lesion was necrosis, with a cellular reaction composed of polymorphonuclear leucocytes with a moderate number of lymphocytes and a few macrophages and plasma cells. Bizarre and distorted nuclei were often seen at the abscess edge, and the lesions contained many Gram-negative bacilli, sometimes slightly curved, which showed slight bipolar staining. These findings are similar to those of earlier workers (e.g. Woolley, 1904, 1905; Sippel, 1955).

Increase of virulence on passage. Several strains were passed five times through guinea-pigs, using large doses (c. $10^{9}$ organisms) grown from heart blood of the animals, and their virulence was tested again. The results are summarized in Table 4, which shows the approximate LD50 doses before and after passage. In a few cases the virulence was significantly but not greatly raised.

The effect of mucin in enhancing virulence. Mucin is well known to increase the virulence of some bacteria on injection. This point was tested for us by Mr G. J. Harper, with strain BH. He found that the LD 50 dose for organisms in broth was about $2 \times 10^{6}$ viable organisms, while that for mucin broth was c. $8 \times 10^{2}$ organisms. 
Table 4. Virulence of Chromobacterium strains for mice and guinea-pigs

The organisms were grown in nutrient broth cultures for $18 \mathrm{hr}$. at $37^{\circ}$, except for strain NT which was grown at $25^{\circ}$ for $48 \mathrm{hr}$. Viable counts were made, and after making suitable dilutions each dilution was inoculated intraperitoneally into ten white mice or five guinea-pigs. The approximate LD 50 dose was obtained by interpolation. Some strains were passed five times in guinea-pigs and then re-tested.

\begin{tabular}{|c|c|c|c|}
\hline & \multicolumn{3}{|c|}{ Test animal } \\
\hline & \multirow[t]{2}{*}{ Mice } & \multicolumn{2}{|c|}{ Guinea-pigs } \\
\hline & & ore passage & After passage \\
\hline \multicolumn{4}{|c|}{ Approximate LD 50 dose of living organisms } \\
\hline FH & Over $10^{8}$ & $10^{9}$ & $10^{8}$ \\
\hline MK & $10^{8}$ & $10^{8}$ & $10^{8}$ \\
\hline BH & $2 \times 10^{6}$ & $10^{7}$ & $10^{6}$ \\
\hline BHR/1 & $10^{7}$ & $5 \times 10^{9}$ & $5 \times 10^{8}$ \\
\hline $\mathbf{B N}$ & $10^{6}$ & $5 \times 10^{6}$ & $10^{6}$ \\
\hline BNR/1 & $10^{7}$ & $10^{\circ}$ & $5 \times 10^{8}$ \\
\hline $\mathbf{A M}$ & $10^{8}$ & $2 \times 10^{10}$ & - \\
\hline MW & Over $10^{8}$ & $5 \times 10^{8}$ & - \\
\hline TV & $5 \times 10^{7}$ & $10^{10}$ & - \\
\hline LG & $10^{7}$ & $10^{9}$ & $10^{7}$ \\
\hline $\mathbf{L W}$ & Over $10^{7}$ & $2 \times 10^{10}$ & - \\
\hline SH & Over $10^{7}$ & $10^{9}$ & $10^{8}$ \\
\hline RT & Over $10^{7}$ & $5 \times 10^{9}$ & $10^{8}$ \\
\hline NT & Over $10^{7}$ & $2 \times 10^{10}$ & - \\
\hline
\end{tabular}

Table 5. The effect of mucin added to inoculum upon virulence

Batches of ten mice were inoculated intraperitoneally with $0.5 \mathrm{ml}$. volumes of living suspensions of strain $\mathbf{B H}$ suspended in broth or in broth $+1.75 \%(w / v)$ mucin.

Number of deaths within

Number of viable $\overbrace{\text { Organisms injected }}^{7 \text { days }}$

$\begin{array}{lrr}8.0 \times 10^{6} & 10 & - \\ 8.0 \times 10^{5} & 0 & 10 \\ 8.0 \times 10^{4} & 0 & 9 \\ 8.0 \times 10^{8} & 0 & 9 \\ 8.0 \times 10^{2} & 0 & 5 \\ 8.0 \times 10^{1} & - & 1 \\ 0 & 0 & 1\end{array}$

- $=$ not tested.

Approximate $\mathrm{LD} 50$ dose without mucin $=5 \times 10^{6}$ organisms.

Approximate LD 50 dose with mucin $=8 \times 10^{2}$ organisms.

Correlation of virulence with source of strain. The most virulent strains, BH and $\mathrm{BN}$, had been isolated from cases of infection in man; the strains isolated from water in Malaya (FH, MK and LG), possess a not much smaller degree of virulence. Other workers (e.g. Gauducheau, 1907; Minett, 1911) also found strains from water to be virulent. Thus it appears that the more virulent water strains may cause natural infections in man.

Toxicity. That the lethal effects of the mesophils are not due entirely to the toxicity of the injected material is suggested by the fact that the LD50 dose 
of living organisms of the more virulent strains is several hundred times lower than that of organisms killed by heat or formalin; the less virulent strains clearly cause death mainly by the toxicity of the inoculum. Dodd (1941) found that the toxic factor in cultures was increased by cultivations in an atmosphere of air containing $25 \%$ carbon dioxide; this toxic factor was filterable. We have not been able to confirm these observations with strain BN, with which we found no effect upon the LD 50 dose of viable organisms by cultivation in $25 \%(\mathrm{v} / \mathrm{v}) \mathrm{CO}_{2}$. Culture filtrates were non-toxic to mice in $1 \mathrm{ml}$. doses intraperitoneally; but strain BN was not the strain used by Dodd. We noted that heat-killed mesophil organisms appeared to be more toxic than formalin-killed organisms, since several rabbits were inadvertently killed by starting immunization to produce $\mathbf{O}$ antisera with too large a dose of heated organisms, while much larger doses of formolized organisms were well tolerated. Dodd also noted that killed organisms were more toxic when given intravenously than intraperitoneally or subcutaneously. It therefore seems possible that haemolysins (probably partly lecithinase, see Sneath, 1956a) are largely responsible. In any event the toxicity of the organism is not very great. With strain MK inoculated intraperitoneally in guinea-pigs, we found that $18 \mathrm{hr}$. broth cultures grown at $37^{\circ}$ were not lethal when injected in $1 \mathrm{ml}$. volumes when the organisms had been killed by heat $\left(100^{\circ}\right.$ for $30 \mathrm{~min}$.) or removed by centrifugation or Seitz filtration, though broth cultures containing living organisms caused death in over half the animals at this dosage (equivalent to c. $9 \cdot 0 \times 10^{6}$ viable organisms). There was thus no evidence for the presence of an exotoxin, and only for a weak endotoxin.

It was shown (Sneath et al. 1953) that mesophilic strains of Chromobacterium produced considerable quantities of hydrogen cyanide; this may perhaps play a part in causing death in infections. But it was not possible to demonstrate by the method of Aldridge (1944) a rise in the concentration of (cyanide + thiocyanate) in the blood of rabbits which died of septicaemia.

\section{DISCUSSION}

The serological results show that Chromobacterium is similar to other Gramnegative bacteria in its antigenic properties. The $O$ antigens of smooth strains tend to be more specific than the rough antigens: heat or ethanol tends to increase the auto-agglutinability of suspensions, and rough strains are of low virulence. The anomalous behaviour of the $H$ antigens may be accounted for by the ability of most strains to develop lateral (peritrichous) flagella when grown on solid media, in addition to the single polar flagellum found on organisms grown in liquid media. The division of the genus into the mesophilic and psychrophilic groups (Leifson, 1956; Sneath, 1956a, 1957) is confirmed by the serology. It is notable that the pathogenic mesophils from cases of natural infection do not form a homogeneous antigenic group; they were previously shown not to form a homogeneous biochemical group (Sneath, 1956a). This is a disadvantage in epidemiological studies, such as that of Sippel (1955), where attempts were made to detect swine which had had subclinical infections, 
since the antibodies resulting from such infections would be mainly strainspecific and would probably not be detected by tests with suspensions of stock laboratory strains. There is some correspondence between the serology of the $\mathrm{O}$ antigens and the composition of the $\mathrm{O}$ polysaccharides from a number of these strain examined by Davies (1955), but the agreement is not as close as it is in Salmonella.

The disease produced by infection with mesophilic strains of Chromobacterium is similar in many ways to melioidosis, as was noted by Darrasse et al. (1955). The clinical picture is similar, and both conditions are generally pyaemias with multiple abscess formation, particularly in liver and lungs, and a high mortality rate. The causative organisms in both diseases appear to be found naturally in stagnant water (see Chambon, 1955), and are evidently of relatively low infectivity in nature. Epizootics with both organisms have been reported in swine (see Nguyen-Ba-Luong, 1956); the histological changes are also similar. However, Chromobacterium and Whitmore's bacillus appear to be quite distinct from each other, both culturally and antigenically.

Although apparently, rare Chromobacterium infections may be more common than is supposed, since the causative organism is likely to be dismissed as a contaminant. Sippel and colleagues studied an epidemic which involved over seventy pigs; they also found that antibodies to their strain was not uncommon in normal pigs. The disease may thus be of some veterinary importance. Sippel (1955) found that Aureomycin was useful for treatment, and Sneath et al. (1953) also had some evidence that this substance was efficacious in man. In the disease in pigs and cattle the evidence (reviewed by Sippel, 1955) suggests that the usual route of entry of the organism is by the mouth; but several authors have been unable to infect small laboratory animals by this route. Sippel et al. (1954) were able to infect pigs by mouth; pigs may be unusually susceptible to infection through the pharyngeal tissues, since the natural cases commonly show cervical adenitis. A similar behaviour is seen with anthrax infection in pigs. In man the site of entry appears to be sometimes through a wound (Schattenberg \& Harris, 1942; Sneath et al. 1953), but more often it is unknown.

\section{REFERENCES}

ALDRIDGe, W. N. (1944). A new method for the estimation of micro quantities of cyanide and thiocyanate. Analyst, 69, 262.

Audebaud, G., Gazin, M., Ceccaldi, J. \& Merveille, P. (1954). Isolement d'un Chromobacterium violaceum à partir des lésions hépatiques observées chez un singe Cercopithecus cephus. Étude et pouvoir pathogène. Ann. Inst. Pasteur, 87, 413.

Bampton, J. H. (1913). Über Violaceus und Membranaceus amethystinus. $Z b l$. Bakt. (I. Abt. Orig.), 71, 129.

BLACK, M. E. \& Shahan, J. (1938). Bacillus violaceus infection in a human being. J. Amer. med. Ass. $110,1270$.

Broudin, L. (1922). Cited in 'Sur un microbe pathogène isolé des eaux de Saigon (Bacillus violaceus acetonicus)'. In Les Instituts Pasteur d'Indochine: Centenaire de Louis Pasteur, 1822-1895, pp. 196-8. Edited by P. N. Bernard. Saigon: Imprimerie Nouvelle Albert Portail.

Chambon, L. (1955). Isolement du bacille de Whitmore à partir du milieu exterieur. Ann. Inst. Pasteur, 89, 229. 
Darrasse, H., Mazaud, R., Giudicelli, P. \& Camain, R. (1955). Un cas humain mortel d'infection à Chromobacterium violaceum (septicémie et multiples abcès hépatiques). Bull. Soc. Pat. exot. 48, 704.

Davies, D. A. L. (1955). The specific polysaccharides of some Gram-negative bacteria. Biochem. J. 59, 696.

DoDD, M. C. (1941). Attempts to infect laboratory animals with strains of Bacillus violaceus isolated from human beings. Dissertation, University of Michigan (University Microfilm Publications No. 319), 104 pp.

Fildes, P. (1920). A new medium for the growth of B. influenzae. Brit. J. exp. Path. 1, 129.

Floch, H. \& de LaJudie, P. (1943). Sur le Chromobacterium violaceum et son pouvoir pathogène chez les animaux et chez l'homme. Institut Pasteur de la Guyane et du Territoire de l'Inini (Archives de l'Institut Pasteur de la Guyane Française), Publication No. 63.

Gauducheau, M. A. (1907). Sur un bacille violet pathogène. C.R. Soc. Biol., Paris, $62,278$.

Gruman, J. P. (1953). Studies on certain species of bacteria assigned to the genus Chromobacterium. J. Bact. 65, 48.

Hartley, P. (1922). The value of Douglas's medium for the production of diphtheria toxin. J. Path. Bact. 25, 479.

Joubert, L. \& NGuYen-VAn-Liem (1957). La chromobactériose animale et humaine. Rev. Elev. n.s. 10, 341.

LeIfson, E. (1956). Morphological and physiological characteristics of the genus Chromobacterium. J. Bact. 71, 393.

Miles, A. A. \& Misra, S. S. (1938). The estimation of the bactericidal power of the blood. J. Hyg., Camb. 38, 732.

MinetT, E. P. (1911). The frequency of Bacillus violaceus in the water and milk supplies of British Guiana. Brit. Guiana med. Annu. No. 18 (1913), p. 44.

Nguyen-ba-Luong (1956). A propos d'une épizootie porcine de mélioidose dans une province méridionale du Vietnam. Bull. Soc. Pat. exot. 49, 25.

Schattenberg, H. J. \& Harris, W. H. (1942). Chromobacterium violaceum var. manilae as a pathogenic microorganism. J. Bact. 44, 509.

Sippel, W. L. (1955). A disease of swine caused by a Chromobacterium species. Ph.D. Dissertation (Veterinary Pathology), Agricultural and Mechanical College of Texas, pp. 9-15, 63-67.

Sipper, W. L., Medina, G. \& Atwood, M. B. (1954). Outbreaks of disease in animals associated with Chromobacterium violaceum. I. The disease in swine. J. Amer. vet. med. Ass. 124, 467.

Sneath, P. H. A. (1956a). Cultural and biochemical characteristics of the genus Chromobacterium. J. gen. Microbiol. 15, 70.

Sneath, P. H. A. $(1956 b)$. The change from polar to peritrichous flagellation in Chromobacterium spp. J. gen. Microbiol. 15, 99.

SNEATH, P. H. A. (1957). The application of computers to taxonomy. J. gen. Microbiol. 17, 201.

Sneath, P. H. A., Whelan, J. P. F., Singh, R. B. \& Edwards, D. (1953). Fatal infection by Chromobacterium violaceum. Lancet, ii, 276.

Wooluey, P. G. (1904). Report on Bacillus violaceus Manilae: a pathogenic microorganism. Bull. Bur. Labs Phil. Is. No. 15.

Woolley, P. G. (1905). Bacillus violaceus Manilae (a pathogenic microorganism). Johns Hopk. Hosp. Bull. 16, 89.

World Health Organization (1954). Expert committee on Biological Standardization: report of 7 th Session, 1953. Wld Hlth Org. tech. Rep. Ser. No. 86, p. 14.

(Received 24 October 1958) 